\title{
Use and Evaluation of Web-based Professional Development Services Across Participant Levels of Support
}

\author{
Steve Whitaker, ${ }^{1,2}$ Mable Kinzie, ${ }^{1}$ Marcia E. Kraft-Sayre, ${ }^{1}$ Andrew Mashburn, ${ }^{1}$ \\ and Robert C. Pianta ${ }^{1}$
}

\begin{abstract}
When participating in a large-scale, web-based professional development program, to what degree do teachers participate? How useful do they find the program? To what degree do they feel supported in their efforts? What are the associations between participation, evaluation of services, and the level of service teachers receive? MyTeachingPartner provides several levels of support to teachers, and each participant's involvement in the project varies in terms of assigned level, frequency of logging in to the site, and the time she spends on it. This paper compared key data sources, including web navigation logs and teacher survey responses, to describe the relationship between teachers' perceptions of support, their specific project interactions, and the level of service they receive. We explored ways that a large-scale professional development project such as MTP can benefit from identifying and nurturing those elements that best foster teacher perceptions of support.
\end{abstract}

KEY WORDS: MyTeachingPartner; professional development; participation; support; perceptions of support; evaluation; web; web-based; online; online professional development; web-based professional development; prek; Pre-K; prek professional development; Pre-K professional development.

\section{INTRODUCTION AND BACKGROUND}

In recent years, more rigorous standards for measuring student achievement and higher levels of accountability have drawn increased attention to the importance of trained, effective teachers. The signing of the No Child Left Behind Act in 2002 mandated state plans for promoting academic achievement for all school children. Now more than ever, the importance of high-quality, ongoing professional development for in-service teachers has become a paramount issue in Pre-K-12 education. Quality teacher training

\footnotetext{
${ }^{1}$ Leadership, Foundations, and Policy, Curry School of Education, University of Virginia, 350 Old Ivy Road, suite 100, Charlottesvlle, VA 22903, USA.

${ }^{2}$ Correspondence should be directed to Steve Whitaker, Leadership, Foundations, and Policy, Curry School of Education, University of Virginia, 350 Old Ivy Road, suite 100, Charlottesvlle, VA 22903, USA; e-mail: whitaker@virginia.edu
}

can help build more effective teacher-child interactions, which can lead in turn to improved child outcomes (NICHD ECCRN, 2002; Maxwell \& Clifford, in press; Cassidy et al., 1995; Howes, 1997).

These outcomes, and thus the need for professional development, are perhaps most important at the Pre-K level. During the year before they enter kindergarten, students have the opportunity to develop skills in language, literacy, and social relationships. These categories of achievement are strong predictors for academic success in later years; their effects are so important that the early years of school are seen as a "critical period" for future success (Alexander \& Entwisle, 1988; Pianta \& Walsh, 1996; Vernon-Feagans, 1996). Despite the importance of teachers' abilities to foster these skills, many Pre-K teachers have little or no knowledge of these subjects, resulting in great variability in both classroom practices and teaching quality (Bryant et al., 2002). This underscores the need for consistent, 
high-quality professional development for Pre-K teachers (Maxwell \& Clifford, in press). Delivering such assistance is made difficult by the fact that there are increasing numbers of Pre-K centers across the United States (Clifford, Early, \& Hills, 1999), as well as by the limited time that teachers have to participate in development opportunities.

The MyTeachingPartner project (MTP) is one potential solution to this problem. MyTeachingPartner is an "at-scale" technology-driven program that provides 235 teachers with professional development resources. The core of these resources includes:

- The MTP Curriculum for Language and Literacy Development (Justice et al., 2003), a 36-week set of child-driven activities that focus upon language and literacy development (see Figure 1);

- Banking Time (Pianta \& Hamre, 2001), a set of techniques designed to build positive, supportive relationships between a teacher and her students; and

- The PATHS Curriculum (Greenberg \& Kusche, 1994), a 36week set of activities designed to promote skills for developing positive social relationships.
The resources were combined in a total package that was tested and refined with the involvement of teachers. (Kinzie et al., 2005).

Teachers were assigned to three study conditions, each of which received different levels of service and support. The hope was that teachers who receive the highest level of support and service would also show the greatest gains in terms of classroom measures and student achievement, and that teachers receiving any service and support beyond what they already receive would show some gains. The three levels of support for MTP are as follows:

- The 66 teachers in the "Materials" group were given an iBook computer and access to a website which contained electronic versions of the MTP Curriculum, Banking Time, and PATHS. The website provided a total of 370 pages. These teachers were not required to access the website, or to implement the curricula.

- The 89 teachers in the "Website Access" or "Web" group also received iBooks, as well as printed versions of the MTP Curriculum and the PATHS curriculum. These teachers were provided all related materials and manipulatives for the curricula, as well as access to the "full-featured" MTP website. This site

\begin{tabular}{|c|c|}
\hline $\begin{array}{l}\text { Spring? } \\
\text { I Area } \\
\text { I Was Walking }\end{array}$ & own the ABC Road \\
\hline \multicolumn{2}{|l|}{ BONUS WEB FEATURES } \\
\hline \multicolumn{2}{|c|}{ 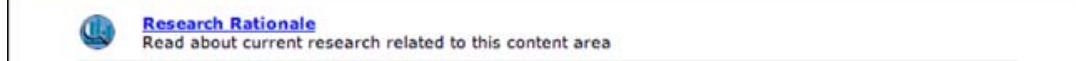 } \\
\hline \multicolumn{2}{|c|}{ 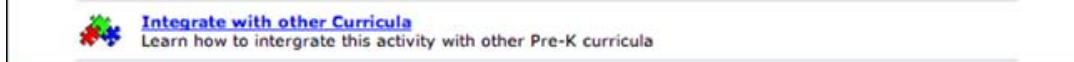 } \\
\hline \multicolumn{2}{|c|}{$\begin{array}{l}\text { Identify by name letters in random order } \\
\text { - Identify common letter sounds }\end{array}$} \\
\hline \multicolumn{2}{|c|}{$\begin{array}{l}\text { GETTING READY } \\
\text { Materials }\end{array}$} \\
\hline \multicolumn{2}{|c|}{$\begin{array}{l}\text { Large or small letter cards } \\
\text { Masking tape } \\
\text { Things to Do Make } \\
\text { Use the masking tape and large or small letter cards to create an ABC road either in your classroom or in another appropriate } \\
\text { space. }\end{array}$} \\
\hline \\
\hline \multirow[t]{2}{*}{ 1. Explain activity } & $\begin{array}{l}\text { We are going to go walking on a special road. The name of this road is the ABC } \\
\text { road. What do you think we will find on this road? Children respond. Yes. We are } \\
\text { going to find letters of the alphabet. }\end{array}$ \\
\hline & $\begin{array}{l}\text { Before doing this activity, determine how many children will go walking on the "ABC } \\
\text { Road" and how many letters you will tape silong it. Depending on your group, you may } \\
\text { choose to walk the "ABC Road" together, in pairs, or individually. }\end{array}$ \\
\hline \multirow[t]{3}{*}{$\begin{array}{l}\text { 2. Identify by name letters in } \\
\text { random order and didentify } \\
\text { common letter sounds }\end{array}$} & $\begin{array}{l}\text { When we find a letter we are going to say the name of that letter and the sound } \\
\text { that letter makes. }\end{array}$ \\
\hline & $\begin{array}{l}\text { Adapt this activity to suit the skill level of your children. If they only know lowercase } \\
\text { letters through } m \text { ' } \mathrm{m} \text { ' use just those letters. If they know all the letters upper and } \\
\text { lowercase then use a variety of letters. }\end{array}$ \\
\hline & $\begin{array}{l}\text { You may put as many or as few letters on the "ABC Road" as you feel the class can } \\
\text { handile. }\end{array}$ \\
\hline
\end{tabular}

Fig. 1. MyTeachingPartner (MTP) language and literacy activity. 
contains everything the Materials group teachers received, as well as additional teacher development resources such as tools for reflecting upon and improving key teaching techniques, video demonstrations of activities, and more. The website provided a total of 1,280 pages. Teachers in this group were not required to regularly use the MTP website, although they were encouraged to, as the site acted as the primary avenue by which teachers could access support services offered by MTP. As a condition of their participation, these teachers were expected to implement both curricula in their classrooms on a daily basis.

- The 80 teachers in the "Consultancy" group received everything the "Web" teachers did, as well as a videoconferencing camera, and the opportunity to participate in a bi-weekly discussion over the internet with a teaching consultant aimed at helping teachers develop their teaching practice. These teachers also received an additional section of the MTP website in which they reviewed video clips of their own teaching (recorded by teachers on videocassettes that are sent to MTP and then edited by their consultants), and to reflect on their strengths as well as opportunities for improvement (Kinzie et al., 2005). The website provided a total of 1,304 pages. Consultancy teachers were required to regularly access the MTP website as part of their participation in the project, as well as implement the two MTP curricula in their classrooms on a daily basis.

\section{RESEARCH QUESTIONS}

Two important considerations of any model of professional development are related to the extent to which teachers are continuing to participate in the process, and whether they feel the project is useful to (and therefore supportive of) their efforts to improve their teaching practice. Kent (2004) notes that in terms of professional development, "the best teachers never assume they have arrived, but constantly strive to refine their practice" (p. 427). This underscores the importance of an ongoing, long-term commitment to professional development on the part of participants - teachers must continue to participate over time (Birman et al., 2000; Guskey, 2003; Kanaya et al., 2005; Lang \& Fox, 2003) and be supported over time (Klinger, 2004) in order to improve their teaching practice.

Effective professional development opportunities include evaluative components (Guskey, 2003; NSDC, 2001) in which participants and others are allowed the chance to express their opinions. Results gathered from responses can be used to improve the overall process-professional development is more effective when teachers feel that development opportunities are connected to their own teaching needs (Boudah \& Mitchell, 1998; Ingvarson et al., 2005). In other words, teachers find professional development more effective when they find it personally and professionally useful.

In traditional models of teacher development, these evaluative tasks can be achieved by simple measures of participation in training opportunities (e.g., workshops), and by opportunities for teachers to express opinions and identify needs. In an at-scale effort like MTP, gauging teachers' sense of the project's usefulness and their engagement in it becomes problematic due to the large number of participants, as well as the geographical distance that separates them. However, such efforts are important, and in this paper we will address the following questions:

- Does participation in MTP vary by the level of service teachers receive?

- Do teachers' perceptions of the value of MTP vary by the level of service they receive?

If there exists a positive correlation between levels of support and project participation, there may be some useful implications for developers of professional development opportunities for teachers-especially as related to the kind and amount of support that should be provided to potential participants.

\section{METHODOLOGY AND DATA SOURCES}

To help gauge teachers' sense of involvement with MTP, and their perceptions of the project's usefulness to their practice, we collected several types of data during the first year of the project.

\section{Data Source: Web Server Logs}

The MTP web server captured data on website use for the 213 teachers who used the website from mid-December, 2004, to mid-June, 2005. For each page a teacher visited after logging in, the server recorded the Uniform Resource Locator (URL, or "address") of the page, and calculated the total number of seconds spent on it. The collection of these data allowed for analysis of the frequency and duration of website visits by individual teachers or of entire participating groups (e.g., Web or Materials).

\section{Data Source: Teacher Evaluation Surveys}

All participants were asked to respond to an endof-year evaluation survey. The web-based survey was tailored to be appropriate for each participant group. Teachers were asked to indicate the frequency of general technology use and the amount of time they 
Table I. Web use data

\begin{tabular}{lcccccc}
\hline & $\begin{array}{l}\text { Total Teachers } \\
\text { Who Logged in }\end{array}$ & $\begin{array}{l}\text { Total Number } \\
\text { of Logins }\end{array}$ & $\begin{array}{l}\text { Logins Per } \\
\text { Teacher } M(S D)\end{array}$ & $\begin{array}{l}\text { Total Time Spent Per } \\
\text { Teacher (mins) } M(S D)\end{array}$ & $\begin{array}{l}\text { Average Session } \\
\text { Length Per Teacher }\end{array}$ & $\begin{array}{l}\text { Average Number } \\
\text { Of Pages Visited } \\
\text { Per Session } M(S D)\end{array}$ \\
\hline Materials & 50 & 319 & $6.38(7.33)$ & $69.50(192.79)$ & $10.89(20.04)$ & $7.69(10.13)$ \\
Web & 79 & 790 & $10.00(12.20)$ & $41.51(58.11)$ & $4.15(8.39)$ & $6.17(7.46)$ \\
Consultancy & 84 & 3,429 & $40.82(28.92)$ & $311.17(280.42)$ & $7.62(11.22)$ & $6.98(6.91)$ \\
All groups & 213 & 4,558 & $21.31(25.41)$ & $153.97(237.35)$ & $7.25(11.76)$ & $6.89(7.29)$ \\
\hline
\end{tabular}

spent on MTP-related tasks and the extent to which they agreed or disagreed with statements about the ease of use and value of various MTP components. A total of 204 teachers completed this survey (an 86.8\% response rate). For both web server and survey data, we used analysis of variance (ANOVA) to determine if significant differences existed between participating groups, and if so, then used post-hoc tests to describe the difference(s) between the three study conditions. Anything below a p-value of 0.05 was considered statistically significant.

\section{Data Source: Focus Groups}

Focus groups held at the end of the year provided additional data related to teacher participation in MTP and perceptions of support in MTP. All participating teachers were offered the opportunity to join one of nine focus groups in which they were asked to share their opinions and ideas about the usefulness of the project, the aspects of it that worked well, and opportunities of improving it. A total of 111 teachers $(47.2 \%$ of total participants) took part: 42 from the Consultancy group $(52.5 \%$ of the total teachers in that group), 55 "Web" teachers (61.8\% of all Web teachers), and 14 "Materials" teachers (17.5\% of that group). Focus group leaders wrote summaries of each meeting, organized by topic (i.e., comments about the Language and Literacy curriculum, PATHS, Technology and the Website, the consultancy [when appropriate], surveys, and assessments). Our project manager reviewed and synthesized these summaries, creating a single summary document (Kraft-Sayre, 2005).

\section{FINDINGS}

The following section presents results for each of the research questions, organized by data source. The statistics and comments are descriptive of teachers' experiences and responses.

\section{Does Participation Vary by the Level of Service Teachers Receive?}

\section{Web Tracking Data}

Web tracking data indicate that 213 teachers logged into the website a total of 4,558 times over the six-month period from mid-December, 2004 to midJune, 2005. This translates to a mean of about 21 logins per teacher, with an average visit of 7.25 minutes. Further examination provides an understanding of between-group differences; relevant data are summarized in Table I.

In terms of logins, an analysis of variance between groups (ANOVA) indicates a significant difference exists $(F(2,210)=66.81, p \leq .05)$, and post-hoc tests indicate that teachers in the Consultancy group logged-on significantly more often than teachers in both the Materials and Web groups. The length of each group's average website visit is significantly different from the others (ANOVA $F(3,211=28.042, p \leq .05)$ : the Materials group teachers spent the most time during each visit, and Consultancy group teachers spent longer than those in the Web group.

\section{Survey Items}

The end-of-year evaluation survey also provided indicators of teacher participation in MTP. Teachers were asked to indicate the frequency with which they performed MTP-related tasks (such as implementing the teaching activities). The Materials group was significantly different from the other two groups in all measures: fewer preparation days per week (ANOVA $F(2,201=46.54)$; fewer preparation minutes each time (ANOVA $F(2,201=15.27)$; fewer delivery days per week (ANOVA $F(2,201=81.26)$; and fewer delivery minutes each time (ANOVA $F(2,201)=$ 26.19). Table II provides summary statistics for the use of MTP's Language and Literacy Curriculum. 
Table II. Frequency and duration of use for MTP language and literacy curriculum

\begin{tabular}{lccccc}
\hline & $\begin{array}{l}\text { Preparation days } \\
\text { Spent Per Week } \\
M(S D)\end{array}$ & $\begin{array}{l}\text { Preparation Minutes } \\
\text { Spent Each Time } M(S D)\end{array}$ & $\begin{array}{l}\text { Delivery Days Spent } \\
\text { Each Week } M(S D)\end{array}$ & $\begin{array}{l}\text { Delivery Minutes } \\
\text { Spent Each Time } \\
M(S D)\end{array}$ & $\begin{array}{l}\text { Prep + Delivery } \\
\text { Total Minutes Spent } \\
M(S D)\end{array}$ \\
\hline Group & $1.02(1.15)$ & $12.07(12.05)$ & $1.39(1.44)$ & $10.43(9.42)$ & $22.50(20.46)$ \\
Materials & $3.32(1.46)$ & $24.11(15.60)$ & $3.86(1.36)$ & $23.29(10.03)$ & $47.41(21.20)$ \\
Cob & $3.32(1.51)$ & $27.78(17.24)$ & $4.16(0.95)$ & $22.35(11.84)$ & $51.14(23.20)$ \\
All groups & $2.80(1.71)$ & $22.82(16.63)$ & $3.42(1.66)$ & $20.42(11.89)$ & $43.24(24.51)$ \\
\hline
\end{tabular}

Table III. Frequency of use for social relationship-building activities

\begin{tabular}{lccc}
\hline & $\begin{array}{l}\text { Weekly Frequency } \\
\text { Weekly Frequency } \\
\text { Of Teaching PATHS } \\
\text { Lessons } M(S D)\end{array}$ & $\begin{array}{l}\text { Of Using PATHS } \\
\text { "Kid of the Day" } \\
\text { Activities } M(S D)\end{array}$ & $\begin{array}{l}\text { Weekly Frequency Of } \\
\text { Using "Banking Time" } \\
\text { Sessions } M(S D)\end{array}$ \\
\hline Materials & - & - & $1.24(0.67)$ \\
Web & $2.96(0.85)$ & $3.90(1.34)$ & $2.23(1.33)$ \\
Consultancy & $3.04(0.74)$ & $4.09(1.37)$ & $2.34(1.25)$ \\
All groups & $3.0(0.80)$ & $3.99(1.35)$ & $2.05(1.26)$ \\
\hline
\end{tabular}

Other survey questions asked teachers about the frequency of their implementation of the social relationship activities. Since these elements were used much less frequently, a different response format was used. Teachers indicated their frequency on a scale of 1 (not at all) to 5 (daily). Materials group teachers implemented Banking Time significantly less often than the other two groups (ANOVA $F(2$, 201) $=14.17, p=.05)$. Materials group teachers did not receive the PATHS curriculum and therefore did not provide responses to these items. No significant differences existed between the Web and Consultancy groups on implementation of the social relations activities. A summary of these data is presented in Table III.

\section{Do Teachers' Perceptions of the Value of MTP Vary by the Level of Service They Receive?}

\section{Survey Items}

Assessing teachers' perceptions of the value of MTP for their teaching practice and professional development was possible through an examination of survey and focus group responses. The first set of survey items related to teachers' sense of being supported in their practice; teachers indicated their level of agreement on a scale of 1 (strongly disagree) to 4 (strongly agree). When asked whether the MTP website adds value to their teaching practice, the Materials teachers' responses were significantly less positive (ANOVA $F(2,201)=9.25)$; than those of

Table IV. Teacher perceptions of value for MTP language and literacy and PATHS curricula

\begin{tabular}{|c|c|c|c|c|c|}
\hline Group & $\begin{array}{l}\text { L\&L Activities } \\
\text { Are Useful For Teaching } \\
\text { Skills That Children In } \\
\text { My Classroom Need } M(S D)\end{array}$ & $\begin{array}{l}\text { L\&L Activities Are More } \\
\text { Useful To Me Than } \\
\text { Other Early Childhood } \\
\text { Curricula } M(S D)\end{array}$ & $\begin{array}{l}\text { L\&L Activities Are } \\
\text { a Valuable Addition } \\
\text { To My Teaching } \\
\text { Practice } M(S D)\end{array}$ & $\begin{array}{l}\text { L\&L Activities Are } \\
\text { Worth The Time I Spend } \\
\text { Preparing And Delivering } \\
\text { Them } M(S D)\end{array}$ & $\begin{array}{l}\text { PATHS Activities } \\
\text { Promote Skills } \\
\text { That The Children } \\
\text { In My Classroom } \\
\text { Need } M(S D)\end{array}$ \\
\hline Materials & $3.17(0.74)$ & $2.37(0.90)$ & $3.60(0.63)$ & $3.60(0.63)$ & $-{ }^{\mathrm{a}}$ \\
\hline Web & $3.68(0.65)$ & $2.85(0.89)$ & $3.62(0.63)$ & $3.59(0.68)$ & $3.52(0.57)$ \\
\hline Consultancy & $3.71(0.58)$ & $3.03(0.57)$ & $3.76(0.53)$ & $3.76(0.57)$ & $3.58(0.61)$ \\
\hline All groups & $3.58(0.68)$ & $2.81(0.88)$ & $3.68(0.59)$ & $3.67(0.62)$ & $3.55(0.59)$ \\
\hline
\end{tabular}

\footnotetext{
${ }^{a}$ Materials group teachers did not receive the PATHS curriculum and therefore were not presented this item
} 
the other two groups. Table IV summarizes teachers' responses to other items about the curricula.

As far as perceived utility of MTP, there were no significant difference between teachers in Consultancy and Web groups, but those in the Materials group responded significantly less positively on all items: the usefulness of activities related to children's needs (ANOVA $F(2,201)=11.66)$; usefulness of activities relative to other curricula (ANOVA $F(2,201)=$ 8.94); whether activities were a valuable addition (ANOVA $F(2,201)=24.49)$ and if activities were worth the time required to use them (ANOVA $F(2,201)=13.65)$.

\section{Focus Groups}

Teachers' responses to focus group questions indicate varied perceptions about the overall usefulness of the project (all quotations and summaries below are from Kraft-Sayre, 2005).

Consultancy Group. Overall, Consultancy group teachers were "impressed at how well-organized the project was," and-more directly related to perceptions of value - "expressed gratitude to be part of the program." Participating Consultancy teachers "feel like they are bettering themselves." Some felt the activities made them more "intentional" in their teaching of literacy skills. There are other indications that this group expressed a high level of perceived usefulness, and many Consultancy teachers indicated that the consultancy itself was the most useful and beneficial component of participating in MTP. Negative comments were generally related to the difficulty of implementing student assessments and the lack of time teachers felt they had to respond to consultants' prompts. There were no negative comments from teachers in this group about the overall usefulness or worth of participating in MTP.

Web Group. Teachers in the Web group also had praise for aspects of the project, but far fewer comments were directly related to perceptions of its professional usefulness. Additionally, there were more negative comments voiced by this group. Most positive comments were directed towards things about the project that teachers "liked," but didn't necessarily find as motivators towards professional improvement. Critical comments from teachers in this group were directed at ways the project could be made more useful to teachers.

Materials Group. Teachers in the Materials group reported a "very positive experience with MTP." Some found the project so beneficial that they purchased, with their own money, materials and manipulatives to use for MTP activities (these had been provided to other groups). The majority of positive comments from this group were similar to those made by the Web group - indicating portions of MTP they appreciated, though not directly connecting them to usefulness in their teaching. The critical comments also followed in the vein of Web teachers' remarks.

\section{DISCUSSION}

\section{Do Degrees of Participation Vary by the Level of Service Teachers Receive?}

Overall, results indicate that teachers' degrees of participation in MTP are associated with the level of service they receive. Regarding the web-based aspects of the project, Consultancy teachers-who receive the highest level of service and the fullest version of the website (1,304 possible pages to visit) - tend to log in more frequently and for longer than teachers in both other groups. And while there is no statistically significant difference between the Web group teachers and the Materials group teachers in terms of login frequency, the amount of time each group spends on the site is significantly different from that of the others, and can also be associated with the level of service teachers receive. While the Materials group teachers logged in less often than other teachers, they spent significantly more time during each website visit than did teachers in either the Consultancy or Web groups, perhaps because this was their only access to the MTP activities (the other two groups received the activities in print as well as web-based form). This would also explain the relatively high number of pages visited per session by teachers in the Materials group. Teachers in all groups visited roughly the same number of pages overall.

The frequency of Consultancy group logins is at least partially explained by the fact that, in order to view the edited videos of their teaching (as required for interaction with their consultant), they must log in to the site at least twice per month. However, this fact only accounts for an average of about 10 logins (the mean number of consultancy "cycles" reported for each teacher); on average, Consultancy teachers are visiting the site more often than that. Although further analysis is necessary to determine what these teachers are doing on the site in each visit, it appears that the viewing of videos does play a significant role in the consultancy group's use of the website: when 
page hits in the "consultancy" section are excluded, consultancy teachers only visit 5.67 pages per login (as compared to 6.98 when including the consultancy section).

When considering participation as a function of implementing MTP activities and other such tasks, Materials group teachers again differ from the other groups. These teachers spend considerably less time preparing to implement and actually implementing the MTP curriculum. This difference is not unexpected; teachers in this group were not expected to implement the curriculum as a condition of their participation.

Do Teachers' Evaluations of the Usefulness of MTP Vary by the Level of Service Participating Teachers Receive?

The level of service received does appear to play a role in teachers' evaluations of the project's usefulness. This is probably due to several factors. Teachers in the Materials group received the lowest level of service, and thus there were fewer things that could be helpful to them - many of the items cited as useful by teachers in the other groups were not provided to Materials group teachers. Further, teachers in this group were not required to use any of the resources they did receive; it is possible that they really never had a chance to find out that some of the MTP activities would have been useful.

Teachers in the two groups (Materials and Web) were similar in their evaluation of the usefulness of key aspects of the project. As both were expected to use both the curricula and the website - and as the contents of both of these items were nearly identical for both groups - it is not surprising that teachers in these groups found the website and items related to the curricula of similar usefulness. The addition of the consultancy service did not influence teachers' perceptions of the value of other components of the MTP service.

\section{LIMITATIONS}

There are several factors which may be considered as limitations in this study. First, there is likely a self-selection process at work as related to Materials teachers' use of - and feelings about - the website and activities. These teachers were not required to use the site or implement the curriculum; as a result, those who chose to participate in these ways probably did so because they expected them to be useful. This preference would likely skew survey responses related to perceptions of usefulness towards more positive responses. Similarly, teachers who participated in focus groups did so voluntarily, presumably because they felt a desire to provide feedback on the project. It is possible that these teachers had more positive opinions to express, which may set them apart from other teachers in their groups.

\section{IMPLICATIONS FOR PRACTICE AND RECOMMENDATIONS FOR FUTURE RESEARCH}

This study indicates a correspondence between the level of support teachers receive and their participation in, and evaluation of, a professional development program. This association implies at least one guideline that may be of benefit for persons developing professional development opportunities for educators.

Teachers will voluntarily spend time participating in a professional development opportunity they find useful. Overall, MTP teachers participated in the project at or above anticipated levels. While consultancy teachers may have been further encouraged to do so through their interactions with their consultants, there were no such checks for web teachers, who participated at levels approximately equal to those of consultancy teachers. Most encouragingly, materials teachers (who were not expected to participate) were also engaged in the project-and, on one measure (length of visits to the website) exceeded levels of participation of teachers in the other two groups. As noted, some materials teachers even purchased resources with their own money, which may indicate that - if provided a professional development opportunity that they deem personally or professionally useful - teachers may be willing to spend some of their own money and time on resources necessary to participate.

This study reports on a preliminary attempt to gauge the associations between the levels of service teachers receive in a professional development program, and their engagement with, and sense of value of, that program. Further research will be useful to describe the impact of the project. Our next step is an attempt to describe how consultation support affects teachers' abilities to be reflective about their own teaching - one of the main goals of the consultancy. We will also describe the effects of teacher participation in MTP on child outcomes - measures of student achievement and growth in the Pre-K year 
and beyond. These approaches will help inform ways to describe the impact of professional development models such as MTP on teaching practice.

\section{REFERENCES}

Alexander, K. L., \& Entwisle, D. R. (1988). Achievement in the first two years of school: Patterns and processes. Monographs of the Society for Research in Child Development, 53 (2, Serial No. 218).

Birman, B. F., Desimone, L., Porter, A. C., \& Garet, M. S. (2000). Designing professional development that works. Educational Leadership, 57(8), 28-33.

Boudah, D. J., \& Mitchell, V. J. (1998). The real thing: A traditionbreaking model, authentic professional development, shows encouraging results. Journal of Staff Development, 19(1), 4347.

Bryant D., Clifford R., Pianta, R. C., Howes, C., \& Burchinal, M. (2002). Characteristics of pre-kindergarten programs in sixstates: Children, teachers, and programs. Applied Developmental Science.

Cassidy, D. J., Buell, M. J., Pugh-Hoese, S., \& Russell, S. (1995). The effect of education on child care teachers' beliefs and classroom quality: Year one evaluation of the TEACH Early Childhood Associate Degree Scholarship Program. Early Childhood Research Quarterly, 10, 171-183.

Clifford, R. M., Early, D. M., \& Hills, T. W. (1999). Almost a million children in school before kindergarten: Who is responsible for early childhood services? Young Children, 54(5), 48-51.

Greenberg, M. T., \& Kusche, C. A. (1994). The PATHS Curriculum. Seattle, WA: Developmental Research and Programs.

Guskey, T. R. (2003). Analyzing lists of the characterists of effective professional development to promote visionary leadership. NASSP Bulletin, 87(637).

Howes, C. (1997). Children's experiences in center-based child care as a function of teacher background and adult-child ratio. Merrill-Palmer Quarterly, 43, 404-425.

Ingvarson, L., Meiers, M., \& Beavis, A. (2005). Factors affecting the impact of professional development programs on teachers' knowledge, practice, student outcomes, and efficacy. Education Policy Analysis Archives, 13 (10). Retrieved 16 September 2005 from http://epaa.asu.edu/epaa/v13n10/.
Justice, L, Pullen, P., Hall, S., \& Pianta, R. (2003). Curry school curriculum for early literacy and oral language support. Unpublished. Charlottesville: University of Virginia.

Kanaya, T., Light, D., \& Culp, K. M (2005). Factors influencing outcomes from a technology-focused professional development program. Journal of Research on Technology in Education, 37(3), 313-329.

Kent, A. M. (2004). Improving teacher quality through professional development. Education, 124(3), 427-435.

Kinzie, M., Whitaker, S. D., Neesen, K., Kelley, M., Matera, M. \& Pianta, R. C. (2005, October). State-wide Web-based Professional Development \& Curricula for Early Childhood Educators: Design \& Infrastructure. Paper presented at the annual meeting of E-Learn, Vancouver, BC.

Klinger, J. K. (2004). The science of professional development. Journal of Learning Disabilities, 37(3), 248-255.

Kraft-Sayre, M. (2005). MyTeachingPartner focus group summary notes [internal document summarizing teachers' comments during a series of focus groups held in the Spring of 2005].

Lang, M., \& Fox, L. (2003). Breaking with tradition: providing effective professional development for instructional personnel supporting students with severe disabilities. Teacher Education and Special Education, 26(1), 17-26.

Maxwell, K. L., \& Clifford, R. M. (in press). Professional development issues in universal kindergarten. In E. Zigler, W. Gilliam \& S. Jones (Eds.), The case for universal preschool education. New York: Cambridge University Press.

National Staff Development Council (2001). NSDC Standards for Staff Development. Available: http://www.nsdc.org/standards/ index.cfm.

NICHD Early Child Care Research Network (2002). Structure $>$ Process $>$ Outcome: Direct and indirect effects of caregiving quality on young children's development. Psychological Science.

Pianta, R., \& Hamre, B. (2001). Students, Teachers, and Relationship Support (STARS). Lutz, FL: Psychological Assessment Resources, Inc. Online: www.parinc.com

Pianta, R. C., \& Walsh, D. J. (1996). High risk children in the schools: Creating sustaining relationships. New York: Routledge.

Vernon-Feagans, L. (1996). Children's talk in communities and classrooms. Cambridge, MA: Blackwell Publishers. 


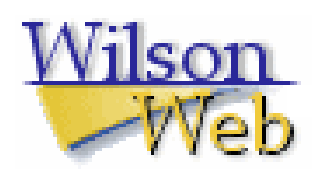

COPYRIGHT INFORMATION

TITLE: Use and Evaluation of Web-based Professional

Development Services Across Participant Levels of Support

SOURCE: Early Child Educ J 34 no6 Je 2007

The magazine publisher is the copyright holder of this article and it is reproduced with permission. Further reproduction of this article in violation of the copyright is prohibited. To contact the publisher:

http://springerlink.metapress.com/content/1573-1707/ 